Milan Acharya ${ }^{1}$

Department of Health, Population and Physical Education

Sanothimi Campus

Tribhuvan University, Kathmandu, Nepal
Original scientific paper

UDC: 371.214 .5

DOI: $10.17810 / 2015.97$

\title{
PROFESSIONAL DEVELOPMENT ACTIVITIES FOR ACTIVITY-BASED LEARNING: CASE OF HIGH SCHOOL HEALTH AND POPULATION TEACHERS IN KATHMANDU, NEPAL
}

\begin{abstract}
In education reform movements, there is an emphasis on health and population education teaching through activity-based instruction. Teacher education is an important part in this process. In this context, this study aims to investigate the effect of activity-based professional development training on high school health and population education teachers' beliefs and self-efficacy. . The data collection tools used was perceptions about activity-based learning strategies, activity-based teaching, self-efficacy and the teaching skills. A group of 30 high school teachers participated in the study. During two days short-term professional development training, the teachers attended four workshops that introduced the activity-based learning method. The analysis of the collected data showed that professional development training was effective in improving teachers' perceptions $(t=-5.39 ; p=$ $0.00)$, self-efficacy $(t=-5.12 ; p=0.00)$, and process skills $(t=-4.99 ; p=0.00)$. The results of the study suggest that provision of workshops ultimately can gear up to the improvement of teachers' self-efficacy learning which transforms the belief system of teachers about teaching and learning by activity-based learning approaches.
\end{abstract}

Keywords: Activity-based learning, community schools, professional development, population education.

\section{INTRODUCTION}

Recent studies have reported that students' motivation in population education as a subject has decreased as has their interest in making a career in these fields (Urdan \& Bruchmann, 2018; Panchaud, et al., 2019; O'Connor, et al., 2018). Although many countries made their efforts to handle this issue, the current situation remained unsatisfactory. Therefore, several countries changed their education systems, including Nepal that adopted an activity-based learning modality in their education systems in order to develop human resources to address this issue (Acharya, 2019a). Activity-based learning strategies in general and in population and health education in particular concern an individual's mental information processing system. This technique emphasizes that knowledge is formed through one's own active physical and mental activities.

Activity-based learning suggests that students should be taken outside the classrooms such as in the garden, playground, nature, and field where they can make queries as part of learning

1milanpanga123@gmail.com 
and they are encouraged to ask questions freely, and hold discussions among peers. This type of learning provides opportunities for students to develop the skills (observing, measuring, collecting data, and drawing conclusions) needed during their life time; they learn to deal with problems that are hard to solve; they accept changes and difficulties in their understanding, and revise for solutions (Acharya, 2019b, Bardovi-Harlig, 2018; Bilgin, Karakuyu, \& Ay, 2015; Trif, 2015).

Researchers have provided ample evidence about the advantages of activity-based learning (Bilgin, Karakuyu, \& Ay, 2015; Trif, 2015). In one of these studies, activity-based learning was implemented in the ninth grade classrooms of five different schools. The results revealed a significant improvement in students' success (Bartholomew, et al., 2018; Hayat, et al., 2017). Activity-based instruction was reported to have been effective in increasing students' academic achievements and developing positive attitudes toward learning (Hayat, et al., 2017); furthermore, it was shown that activity-based learning ( $A B L$ ) contributes to individuals' physical development and skills as a team and helps the development of reading, writing, and life skills (Yaneva, 2017).

In activity-based learning approach, population education teachers' roles vary as diagnostic, motivator, guide, innovator, experimenter, investigator, modeller, advisor, collaborator, and learner (Acharya, 2019c, Bardovi-Harlig, 2018; Bilgin, Karakuyu, \& Ay, 2015; \& Trif, 2015). Study of $A B L$ mentioned that teachers must encourage students to discuss their views and explore and put forward their ideas by asking questions that lead to critical thinking, and must provide students with enough time to answer (Bilgin, Karakuyu, \& Ay, 2015; Liu, 2017). Some research, however, has revealed inadequate implementation of activities in learning. According to these findings, teachers stated some reasons such as: (i) they were reluctant to use $A B L$ because of their inadequate knowledge (Lederman, 1992); (ii) they lacked experience of using $A B L$ (Arslan, et al., 2014; Kleine, et al., 2002); (iii) they had beliefs about physical activity as it is appropriate for only bright students; and (iv) there was a discrepancy between content of population and teachers' perceptions (Keys \& Kang, 2000; Wallace \& Kang, 2004; Windschitl, 2002).

It is important for teachers to have a thorough understanding of and develop awareness about the learning and teaching skills in population to implement ABL. Students make observations, ask questions, design rules, establish a hypothesis, test the hypothesis by making predictions and interpreting the results, and share findings with others. $A B L$ causes skill development in the learners and use the skills further. Similarly, it is necessary that, in addition to the subject matter knowledge, teachers need to have knowledge about process skills so that they can engage the learners in the learning process better. The existing literature has also reports that students gaining of process skills varies statistically according to the teachers' level of using teaching skills (Acharya, 2016, Keys \& Kang, 2000).

Studies have also indicated that curriculum reform movements are shaped and changed by teachers' understanding and beliefs (Trif, 2015); reform movements in education require changes in teachers' beliefs and values (Keys \& Kang, 2000), and teachers return to traditional curricula in the absence of professional training (Bilgin, Karakuyu, \& Ay, 2015; \& Trif, 2015). Researchers have thus regarded it as important to provide professional development and other support to teachers in order to help them implement activity-based learning. In this context, successful professional development training can lead to these benefits like: (i) it can help in changing teachers' beliefs and practices (Cohen \& Hill, 2000); (ii) it is an important aid 
for teachers to determine the aims that affect students' behaviours in classrooms and schools (Young, 2001); (iii) it provides ways to increase students' academic achievement (Falk, 2001 cited by Villegas-Reimers, 2003); (iv) it helps teachers in creating an investigator class culture and IBL experiences (Cohen \& Hill, 2000); ( $v$ ) it causes positive, strong, and important development in terms of teachers' attitudes and practices (Young, 2001); and (vi) it provides means for teachers to keep their knowledge and skills up to date (European Union, 2010).

This study, distinct from previous studies, included teaching skills and formative assessment training strategies for professional development of high school population teachers in the public schools in Nepal. This study aimed to investigate the effect of activity-based professional development activities on school teachers' teaching skills, perceptions about the activity-based learning method, and self-efficacy beliefs. The study asked these questions to be inquired: (i) is there any significant difference between teachers' pre-test and post-test scores on the tool 'teaching skills test'?; (ii) is there any significant difference between population teachers' pre-test and post-test scores on the tool 'activity-based learning selfefficacy scale'?; and (iii) is there any significant difference between teachers' pre-test and post-test scores on the tool 'beliefs about activity-based teaching scale'?

\section{Method and Methodology}

\section{Research Design}

In this study, one group pre-test post-test design experimental design was used. In this model, measurements of one group were made before and after the intervention. According to this model, if post-tests have higher scores than pre-tests, it is due to the effectiveness of the treatment. However, to increase the validity of this study, qualitative and quantitative measurements were considered in the data collection process. The experimental process of this research is as follows:

Table 1. Experimental Process of the Research

\begin{tabular}{clll}
\hline Teachers & Pre-test & Implementation & Post-test \\
\hline Population & -Teachers process skills & Activity-based & -Teaching process skills test \\
teachers & test & $\begin{array}{l}\text { professional } \\
\text { development }\end{array}$ & -The activity-based teaching \\
& -Activity-based learning & sefficacy scale \\
& -Teaching self-efficacy & activities & -Beliefs about activity-based \\
& scale & & teaching scale \\
& -Beliefs about activity- & & -Semi-structured interviews \\
based learning & & \\
\hline
\end{tabular}

\section{Participants}

Teachers' volunteerism and accessibility was the basis for the selection of participants. Hence convenience sampling wasapplied in this study. Thirty teachers (17 female and 13 male) fromfifteen high schools in Kathmandu valley participated in the study. Three of the female teachers had 0-5 years of teaching experience, two of them had 6-10 years, three of them had 11-15 years, and nine of them had 16 years and more. Similarly, three of the male teachers had $0-5$ years of experience, two had 6-10 years, and eight had 16 years and more. 


\section{Data Collection Tools}

Teaching process skill tests, the activity-based teaching self-efficacy scale, perception about activity-based teaching scale, and semi-structured interviews were the tools used to collect the data.

Teaching Process Skills Test: This test was used to determine changes in teachers' process skills. It included 31 multiple-choice questions with reliability coefficient was 0.81 . This study only used 10 questions related to skills (observations, hypothesizing, predicting, planning and investigating, and interpretation) in professional development training.

Activity-based Teaching Self-efficacy Scale: This scale was originally developed by Smolleck (2008). It comprises 69 five-point Likert-type items, and the Cronbach alpha value of the scale is reported as 0.83 .

The Perceptions of Activity-based Teaching Scale: Perceptions of Activity-based Teaching Scale (PABTS)was used to determine whether a change in teachers' perceptions about activitybased teaching had occurred. The scale comprised two parts consisting 44 items. In the adaptation process, the scale was applied to 30 pre-service high schoolteachers. Validity and reliability studies were performed on the obtained data. As a result of factor analysis, it was noted that the first part of the scale comprises only one factor called characteristics of activity-based teaching, the second part of the scale comprised two factors called barriers related to method and barriers related to teachers' lack of knowledge. The Cronbach alpha reliability value was found 0.87 for the first part and 0.83 for the second part. The Cronbach alpha value for the whole scale was 0.78 .

Semi-structured interviews: Interviews were conducted upon four randomly selected teachers the training package was conducted in order to determine their views about training and activity-based teaching. To provide validity, the study utilized the views of two teaching staff members and three research assistants.

\section{Data Analysis}

To analyse the quantitative data, a paired sample t-test was conducted by using the software SPSS. The level of significance in this comparison was determined to be 0.05. In the analysis of the qualitative data obtained from the semi-structured interviews, the teachers' statements were recorded with their permission and then transcribed.

\section{FINDINGS}

Table 2 shows the statistical scores of teachers' answers to the quantitative data collection tools before and after the training packages in the teachers' professional development programme.

Table 2.Teachers' Answers and Results of t-test in Pre-test and Post-test

\begin{tabular}{lccccc}
\hline & $\mathrm{N}$ & $\mathrm{X}$ & $\mathrm{sd}$ & $\mathrm{t}$ & $\mathrm{p}$ \\
\hline Teaching skills test scale & & & & & \\
Pre-test & 30 & 13.53 & 1.83 & & \\
Post-test & 30 & 15.47 & 1.68 & -4.23 & $0.00^{*}$ \\
Activity-based learning self-efficacy scale & & & & \\
\hline
\end{tabular}




\begin{tabular}{|c|c|c|c|c|c|}
\hline & 30 & 255.07 & 12.78 & & \\
\hline & 30 & 273.30 & 18.04 & -5.12 & $0.00 *$ \\
\hline \multicolumn{6}{|l|}{$\begin{array}{l}\text { Perceptions about activity- } \\
\text { based learning }\end{array}$} \\
\hline Importance of $A B L$ pre-test & 30 & 70.87 & 4.31 & & \\
\hline Importance of $A B L$ post-test & 30 & $75 \cdot 47$ & 3.32 & -6.57 & $0.00 *$ \\
\hline Teaching skills pre-test & 30 & 64.13 & 5.67 & & \\
\hline Teaching skills post-test & 30 & 68.70 & 7.74 & -3.39 & $0.00 *$ \\
\hline $\begin{array}{l}\text { Learning perceptions pre- } \\
\text { test }\end{array}$ & 30 & 40.30 & 10.27 & & \\
\hline $\begin{array}{l}\text { Learning perceptions post- } \\
\text { test }\end{array}$ & 30 & 38.23 & 9.67 & 1.49 & 0.14 \\
\hline Difficulties pre-test & 30 & 50.77 & 6.70 & & \\
\hline Difficulties post-test & 30 & 60.33 & 7.06 & -4.99 & $0.00^{*}$ \\
\hline
\end{tabular}

${ }^{*} p<.05$ difference is significance

High school teachers who attended teachers' professional development training package showed significant development in terms of teaching skills, self-efficacy on activity-based teaching and learning. According to Table 2, only the post-test score of the activity learning method was decreased. The data obtained from the semi-structured interviews also supported positive gains related to variables. After the teaching process skills activities, teachers stated that before the workshop, they had inadequate knowledge about the techniques of teaching process skills, and they learned new skills in the teachers' professional development programme. One of the teachers (T4) said, "I learned the concept of making activity-based teaching and learning. These methods are simple and make students active in their own work. It increases collaborative skills among them. Now, I learned the importance of outdoor activities for meaningful engagement of students to learn on their own".

Among the sampled teachers, $\mathrm{T} 4, \mathrm{~T} 8, \mathrm{~T} 9$, and $\mathrm{T} 2$ stated that "perceptions about the activitybased learning method as well as their self-efficacy beliefs changed and improved. We have to engage students in outside environment to explore their potentialities". In this context, the majority of teachers made comparisons between their lessons before and after the intervention, and realized the contributions of the activities to students. They expressed the views of changing in their teaching and learning techniques. Some sample expressions made by the teachers are:

Teacher (T18) said, "I think that activity-based learning method can encourage students for collaborative learning".

"I think that traditional activities create a more restricted learning environment for students. But [in this modality] the students became free to investigate and make experiments in outdoor activities. For this reason, I think that inquiry activities can lead students to become more responsible in their learning through research" (Teacher T13).

"Activity-based approach to teaching and learning method allows students to query via their own hypothesis instead of accepting information directly and it increases the retention of information"(Teacher T3).

Similarly, teacher (T19) claimed "instructions of activities in our lessons are clear and so students' working is more restricted and they are not free. I think that teaching a lesson like this can be more enjoyable and students become more active".

Furthermore, teacher (T8) argued as similar with the teacher (T3) and said, "instructions of activities in my lesson were given clearly and they hadn't been adapted to activities. After this 
programme, I realized that I allowed my students to query in a limited way. They didn't query by their own hypothesis. Now I am aware of an open environment to open their potentialities".

From the above opinions of the teachers, it is concluded that the teachers' professional development programme is helpful to transform the classroom pedagogy from teachercentred to student-centred approach among community level high schools health and population teachers.

\section{DISCUSSION AND CONCLUSION}

This study was conducted to test the hypothesis that activity-based learning professional development activities affect community high school health and population teachers' teaching skills and their self-efficacy. So, the first problem was "is there any significant difference between teachers' pre-test and post-test scores on the teaching skills test?" The analysis showed a statistically significant increase in teachers' scores.

The second problem was "is there any significant difference between teachers" pre-test and post-test scores on the activity-based teaching self-efficacy scale?" The analysis related to this showed that there was a significant development in teachers' self-efficacy perceptions after the intervention. During the teachers' professional development programme, it was emphasized that practicing the activity-based method is not as difficult as it is thought, and it can be practiced by making small changes in activities which will have a large effect on learning. This may have affected teachers' self-efficacy beliefs. The result supports the findings of other studies indicating that introductory workshops about student-centred teaching are effective to develop teachers' self-efficacy beliefs (Eshach, 2003) and that professional development trainings increase teachers' self-efficacy from a low level to a high level (Roberts, et al., 2001).

The third question of this research was "is there any significant difference between teachers' pre-test and post-test scores on the beliefs about activity-based teaching scale?" The result showed that there was a significant development in teachers' scores on the importance attributed to activities, their thoughts related to the frequency of using student-centred classes, and the perceived potential barriers about class on the playground and in the school garden. Consistent with the results of other studies, the findings of this study indicate that professional development has a positive effect on teachers' views about student-centred teaching (Roberts, et al., 2001), teachers' understanding (Acharya, 2016, Lotter et. al., 2007) and beliefs (Cohen \&Mill, 2000). The fact that some teachers maintain negative beliefs about students' activities in the interviews may be a result of their lack of experience in the past. The results in the literature report that teachers' negative beliefs about the student-centred method may stem from their inexperience about this method when they were college students and novice teachers (Roberts, et al., 2001).

Future studies can investigate the extent to which teachers reflect their gains obtained from professional development training to their learning environments and the advantages of this reflection in terms of students and classroom culture to transform high school population classes at the community schools of Nepal. 


\section{Acknowledgements}

I would like to thank to all the teachers of health and population education who actively participated in this study. Also, I would like to thank all my colleagues, seniors and professors of Health, Population and Physical education for scholarly guidance and encouragement to prepare this article.

Any opinions, findings, and conclusions made here are those of the author and the participants and should not be necessarily attributed to the Ministry of Education (MoE), Government of Nepal.

\section{References}

Acharya, K. P. (2019a). Demystifying Science Teachers' Epistemic Belief on Chemical Concepts: Students' Engagement in the School Garden, Pedagogical Research, 4(4),

Acharya, K. P. (2019b). New Perspectives on Activity-Based Chemistry Learning through Meaningful Engagement: Mystical Improvement in Students' Achievement, American Journal of Creative Education, 2(3), 128-137.

Acharya, K. P. (2019c). Inquiry-based science learning through school gardening activities: Wonderful experience through participatory action research, International Journal of Elementary Education, 7(3), 40-45.

Acharya, K. P. (2016). Fostering critical thinking practices at primary science classrooms in Nepal. Research in Pedagogy, 6(2), 1-7.

Arslan, A., Ogan Bekiroglu, F., Suzuk, E. \& Gurel, C. (2014). Fizik laboratuvar derslerinin arastirma-sorgulama acisindan incelenmesi ve ogretmen adaylarinin goruslerinin belirlenmesi, Turk Fen Egitimi Dergisi, 11 (2), 3-37.

Bardovi-Harlig, K. (2018). Teaching of Pragmatics, The TESOL Encyclopedia of English Language Teaching, 1-7.

Bartholomew, J. B., Jowers, E. M., Roberts, G., Fall, A. M., Errisuriz, V. L., \& Vaughn, S. (2018). Active Learning Increases Children's Physical Activity across Demographic Subgroups, Translational Journal of the American College of Sports Medicine, 3(1), 1-9.

Bilgin, I., Karakuyu, Y., \& Ay, Y. (2015). The effects of project based learning on undergraduate students' achievement and self-efficacy beliefs towards science teaching, Eurasia Journal of Mathematics, Science \& Technology Education, 11(3), 469-477.

Cohen, D.K. \& Hill, H.C. (2000). Instructional policy and classroom performance: The mathematics reform in California,Teachers College Record, 102, 294-343.

Eshach, H. (2003). Inquiry-events as a tool for changing science teaching efficacy beliefs of kindergarden and elementary school teachers, Journal of Science Education and Technology, 12 84), 495-501.

European Union (2010). Teachers' Professional Development Europe in International Comparison: An Analysis of Teachers' Professional Development based on the OECD's Teaching and Learning International Survey (TALIS). Luxemburg: Office for Official Publications of the European Communities.

Hayat, M., Hasan, R., Ali, S. I., \& Kaleem, M. (2017). Active learning and student engagement using Activity Based Learning. In 2017 International Conference on Infocom Technologies and Unmanned Systems (Trends and Future Directions)(ICTUS) (pp. 201204). IEEE. 
Keys, C.W., \& Kang, N.H. (2000). Secondary science teachers' beliefs about inquiry: A starting place for reform. Paper presented at the annual meeting of the National Association for Research in Science Teaching, New Orleans, LA.

Kleine, K., Brown, B., Harte, B., Hilson, Malone, D. \& Moller, K. (2002). Examining inquiry, Principal Leadership, 3(3), 36-39.

Liu, I. W. (2017). The Effects Of Debate Instruction Through A Flipped Learning Environment On Speaking Ability And Critical Thinking Skills Of Thai High School Students (Doctoral dissertation, Chulalongkorn University).

Lotter, C., Harwood, W.S., \& Bonner, J.J. (2007). The influence of core teaching conceptions on teachers' use of inquiry teaching practices, Journal of Research in Science Teaching, 38(6), 650-661.

O'Connor, C. A., Dyson, J., Cowdell, F., \& Watson, R. (2018). Do universal school-based mental health promotion programmes improve the mental health and emotional wellbeing of young people? A literature review, Journal of clinical nursing, 27(3-4), 412-426.

Panchaud, C., Keogh, S. C., Stillman, M., Awusabo-Asare, K., Motta, A., Sidze, E., \& Monzón, A. S. (2019). Towards comprehensive sexuality education: a comparative analysis of the policy environment surrounding school-based sexuality education in Ghana, Peru, Kenya and Guatemala, Sex Education, 19(3), 277-296.

Roberts, J.K., Henson, R.K., Tharp, B.Z. \& Moreno, N.P. (2001). An examination of change in teacher self-efficacy beliefs in science education based on duration of in-service activities, Journal of Science Teacher Education, 12 (3), 199-213.

Smolleck, L. A. \& Yoder, E.P. (2008). Further development and validation of the teaching science as inquiry (TSI) instrument, School Science and Mathematics, 108(7), 291-297.

Trif, L. (2015). Training models of social constructivism. Teaching based on developing a scaffold, Procedia-Social and Behavioural Sciences, 180, 978-983.

Urdan, T., \& Bruchmann, K. (2018). Examining the academic motivation of a diverse student population: A consideration of methodology, Educational Psychologist, 53(2), 114-130.

Villegas-Reimers, E. (2003). Teacher professional development: An international review of the literature, Paris: International Institute for Educational Planning.

Wallace, C. S. \& Kang, N. (2004). An investigation of experienced secondary science teachers' beliefs about Inquiry: An examination of competing belief sets, Journal of Research in Science Teaching, 41(9), 936-960.

Windschitl, M. (2002). Inquiry projects in science teacher education: What can investigate experience reveal about teacher thinking and eventual classroom practice? Science Teacher Education, 87, 112-143.

Yaneva, A. (2017). Research On The Physical Development And Activity Of Students Training Judo Sport At Sofia University. Activities in Physical Education \& Sport, 7(1).

Young, P. (2001). District and state policy influences on professional development and school capacity, Educational Policy, 15(2), 278-301.

\section{Biographical notes:}

Mrs Milan Acharya, is currently involved in teaching Population Education at the Department of Health, Population and Physical Education, Sanothimi Campus, Tribhuvan University, Kathmandu, Nepal. She teaches research methodology, population education and environmental education to the graduate and post graduate students. She researches and publishes in the field of health and population education in Nepal and abroad. 